\title{
Isotope and Geochemistry Characterization of Hot Springs and Cold Springs of Sembalun - Rinjani Area, East Lombok, West Nusa Tenggara - Indonesia
}

\author{
Satrio Satrio ${ }^{1, *}$, Rasi Prasetio ${ }^{1}$, Boy Yoseph Cahya Sunan Sakti Syah Alam ${ }^{2}$, Teuku Yan Waliyana \\ Muda Iskandarsyah ${ }^{2}$, Faizal Muhammadsyah², Mohamad Sapari Dwi Hadian², and Hendarmawan \\ Hendarmawan ${ }^{2}$ \\ ${ }^{1}$ Center for Isotopes and Radiation Application - BATAN, Jl. Lebak Bulus Raya No. 49, Jakarta 12440 Indonesia \\ ${ }^{2}$ Faculty of Geological Engineering, Padjadjaran University, Jl. Raya Bandung Sumedang Km 21, \\ Jatinangor, Sumedang 45363 Indonesia
}

${ }^{*}$ Corresponding author:

tel: $+62-813-87609230$

email: satrio@batan.go.id

Received: October 23, 2019

Accepted: March 18, 2020

DOI: $10.22146 /$ ijc. 50790

\begin{abstract}
The presence of several hot springs in Sembalun - Rinjani, East Lombok, West Nusa Tenggara is an indicator of geothermal potential in the area. This study aims to determine the characteristics of hot springs and cold springs and also the geothermal potential in Sembalun - Rinjani area using isotopes and geochemistry methods. The result of $\delta^{18} \mathrm{O}$ and $\delta^{2} \mathrm{H}$ stable isotopes analysis shows that most of the hot springs are meteoric water. Except for Kalak hot spring, other hot springs are a mixing product of meteoric water and andesitic water, with meteoric water composition between 64 to $87 \%$. While ${ }^{14} C$ radioisotope suggests that the age of hot springs in the Sembalun area is about 10,000-12,000 years BP, the surrounding cold springs are mostly Modern except Jorong cold spring. The results of gas analysis ( $\mathrm{He}, \mathrm{Ar}$, and $\mathrm{Ne}$ ) also suggest the same origin of geothermal fluid, i.e., meteoric water origin. Based on chemical composition, Kalak hot spring is plotted as sulfate type water, while Sebau hot spring is plotted near mature water composition but not representing reservoir fluid due to its relatively low temperature and high $\mathrm{Mg}$ content. $\mathrm{Na} / \mathrm{K}$ geothermometer calculation from Sembalun area shows that subsurface temperature is varied between $111-161{ }^{\circ} \mathrm{C}$, while from Rinjani hot springs indicates higher subsurface temperature, i.e., $250-260^{\circ} \mathrm{C}$. It is estimated that reservoir fluid has high TDS with chloride content up to $4000 \mathrm{mg} / \mathrm{L}$.
\end{abstract}

Keywords: geothermal; Sembalun - Rinjani; hot spring; cold spring; isotope; geochemistry; geothermometer

\section{- INTRODUCTION}

Sembalun is located on the east flank of Mount Rinjani, East Lombok Regency, Lombok Island Indonesia. Geographically, Sembalun is surrounded by mountainous hills with elevation about 800-1100 $\mathrm{m}$ above sea level, around $60 \mathrm{~km}$ from Mataram, the capital city of West Nusa Tenggara Province. There are several cold springs in the valley of Sembalun that being uses by surrounded villagers for daily use and agricultural use, while some hot springs also emerge from this area, namely Kalak, Orok, and Sebau. Some hot springs with higher temperatures also emerge at a higher elevation, near Segara
Anak Lake, a crater lake of Rinjani Mountain. The presence of several hot springs in the area is an indicator of geothermal energy potential, thus might be utilized to meet electricity demand in Lombok Island. Based on previous work, the Ministry of Energy and Mineral Resources has identified the prospective of the Sembalun area to be developed for its geothermal energy [1]. The aim of this current study is to determine the characteristics of hot springs and cold springs and asses its geothermal potential using isotopes and geochemistry data in the hydrogeological framework. The study utilized stable isotopes of water, i.e., ${ }^{2} \mathrm{H}$ and ${ }^{18} \mathrm{O}$, to investigate the origin of fluids and its interaction with surrounding rocks [2- 
3 ], while ${ }^{14} \mathrm{C}$ radioisotope is used to determine groundwater age [4-5]. In addition, a fluid geochemistry approach is used to determine the characteristics and temperature of the reservoir [6]. The result of this study will bring benefits as support for the development of Sembalun - Rinjani geothermal prospect, especially as electricity generation.

\section{- EXPERIMENTAL SECTION}

\section{Study Area}

The study area is located at Suela, Aikmal and Sembalun Districts, East Lombok Regency, West Nusa Tenggara with geographical coordinate between $116^{\circ} 30^{\prime} 00^{\prime \prime} \mathrm{E}$ to $116^{\circ} 35^{\prime} 00^{\prime \prime} \mathrm{E}$ and $8^{\circ} 20^{\prime} 30^{\prime \prime} \mathrm{S}$ to $8^{\circ} 30^{\prime} 00^{\prime \prime} \mathrm{S}$, covering $10 \times 19 \mathrm{~km}^{2}$ [7]. The location of sampling sites in the study area can be seen in Fig. 1.

Samples were taken in some thermal manifestations such as hot springs and gas bubbles, as well as groundwater and surface water as a comparison. During the sampling, field measurements were also conducted, i.e., temperature, $\mathrm{pH}$, and electric conductivity.

\section{Procedure}

\section{Water sampling}

Water samples were taken at the discharge point of the spring. Samples for cation analysis were acidified with
$\mathrm{HNO}_{3}$, while samples for anion analysis were not acidified [8]. Samples for isotopes analysis $\left({ }^{18} \mathrm{O}\right.$ and $\left.{ }^{2} \mathrm{H}\right)$ were collected in $30 \mathrm{~mL}$ air-tight bottle with no air bubbles to minimize isotope fractionation [9]. Meanwhile, samples for groundwater dating $\left({ }^{14} \mathrm{C}\right.$ analysis) were collected as much as $60 \mathrm{~L}$, followed by in situ precipitation of carbonates using barium chloride and coagulation agent. The barium carbonate precipitation was then collected and brought to the laboratory [10].

\section{Gas sampling}

Gas sampling was done using the Giggenbach flask (Fig. 2), an evacuated glass-bottle filled with $4 \mathrm{~N} \mathrm{NaOH}$ [11]. Steam from fumaroles is condensed inside the bottle, while acidic gases, i.e., $\mathrm{CO}_{2}$ and $\mathrm{H}_{2} \mathrm{~S}$, will be dissolved in $\mathrm{NaOH}$ solution as carbonate and sulfide. Other minor gases, i.e., $\mathrm{H}_{2}, \mathrm{He}, \mathrm{Ar}, \mathrm{O}_{2}, \mathrm{~N}_{2}, \mathrm{CH}_{4}$, will occupy the headspace above $\mathrm{NaOH}$ solution. During the sampling, the glass bottle is connected with fumarole using silicone hose and titanium funnel or titanium tube. Clay was placed around the vent to minimize air contamination [12].

\section{Analysis of stable isotopes of ${ }^{2} \mathrm{H}$ and ${ }^{18} \mathrm{O}$}

Analysis of stable isotopes was done by laser spectroscopic method, i.e., using LGR (Los Gatos Research) DLT-100 Liquid Water Isotope Analyzer. The

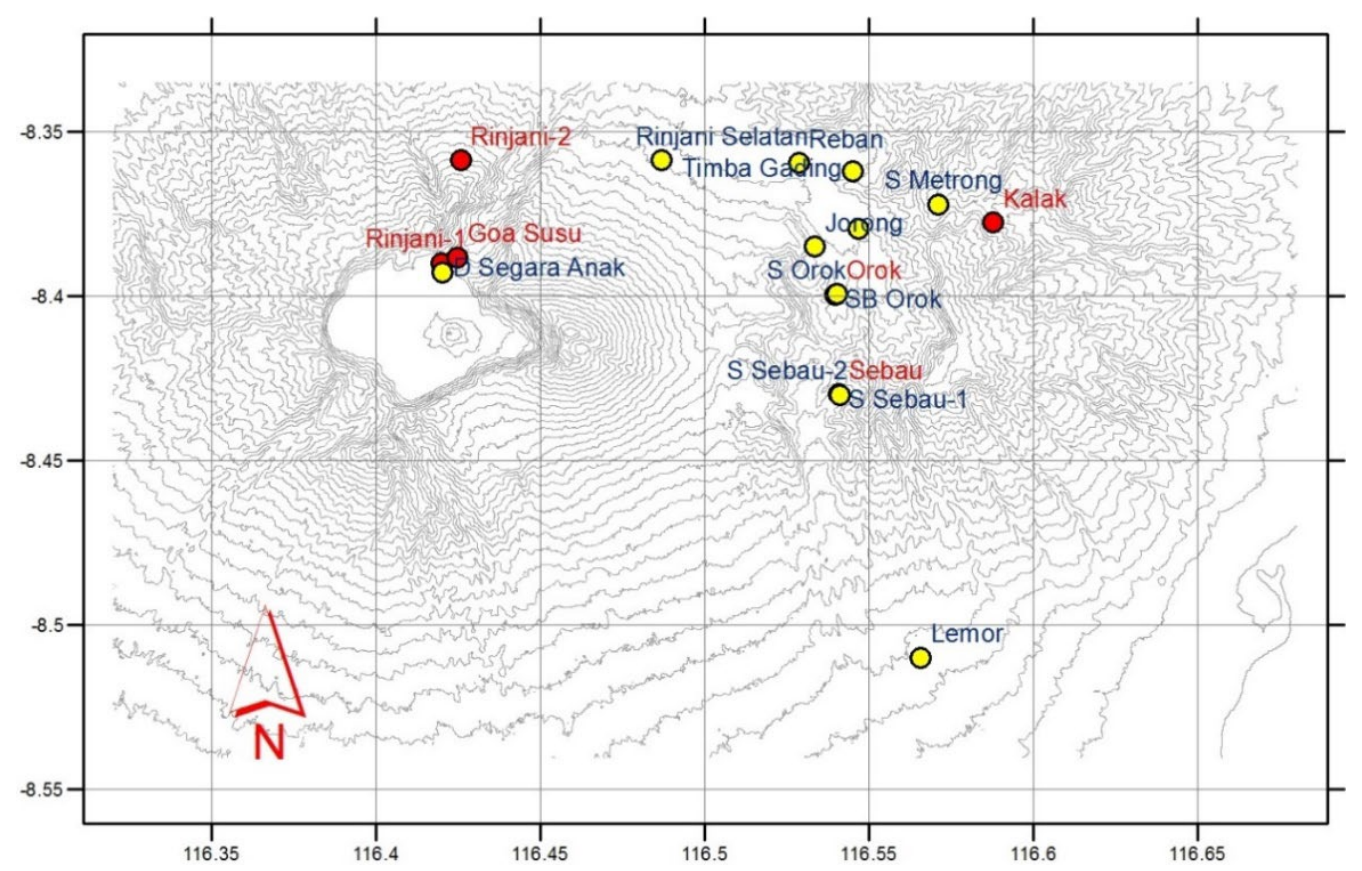

Fig 1. Sampling location at mount Rinjani and Sembalun area 


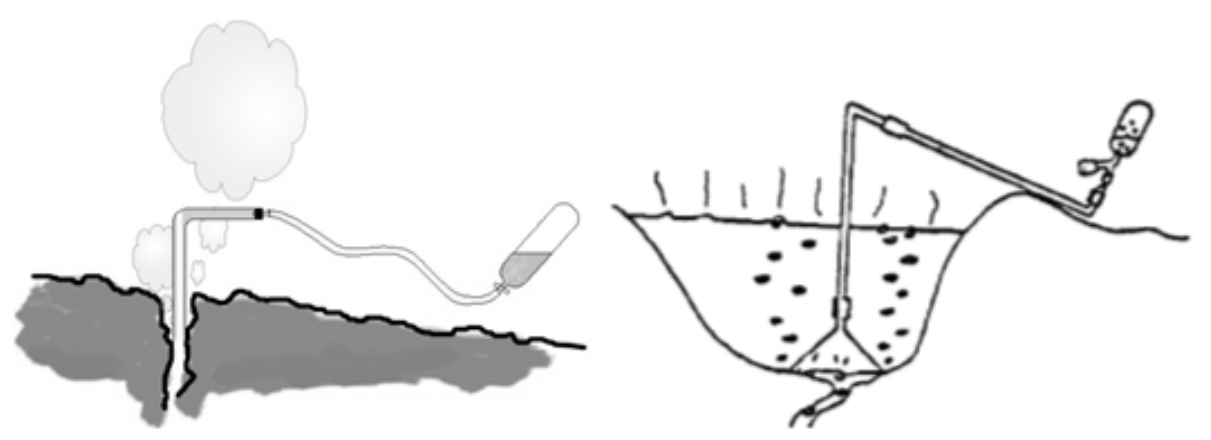

Fig 2. Sampling scheme

value of isotope composition $(\delta)$ is expressed in \%o unit, i.e., relative deviation of isotope ratio of a sample against isotope ratio Standard Mean Oceanic Water (SMOW) as defined by the following equation [13-14]:

$\delta=\frac{\mathrm{R}_{\text {Sample }}-\mathrm{R}_{\text {SMOW }}}{\mathrm{R}_{\text {SMOW }}} \times 1000 \%$

where, $\mathrm{R}_{\text {Sample }}=$ the isotope ratio $\left(\delta^{2} \mathrm{H}\right.$ or $\left.\delta^{18} \mathrm{O}\right)$ of the sample; $\mathrm{R}_{\text {SMOW }}=$ the isotope ratio $\left(\delta^{2} \mathrm{H}\right.$ or $\left.\delta^{18} \mathrm{O}\right)$ of the SMOW

\section{Analysis of radiocarbon $\left({ }^{14} \mathrm{C}\right)$}

Radiocarbon dating was prepared by reacting $\mathrm{BaCO}_{3}$ precipitation from a sample with $10 \% \mathrm{HCl}$ in preparation line, producing $\mathrm{CO}_{2}$ gas.

$\mathrm{BaCO}_{3}+2 \mathrm{HCl} \rightarrow \mathrm{BaCl}_{2}+\mathrm{H}_{2} \mathrm{O}+\mathrm{CO}_{2}$

The produced $\mathrm{CO}_{2}$ is then absorbed using $30 \mathrm{~mL}$ of $1: 1$ Carbosorb-E and Permafluor-E [15] and counted using Liquid Scintillation Analyzer (LSA) Perkin Elmer TriCarb 2910TR.

\section{Analysis of water chemistry}

Analysis of water chemistry was done using several methods, i.e., acid-base titration for $\mathrm{HCO}_{3}{ }^{-}$using $\mathrm{HCl}$ as the titrant, while ion chromatography was used to analyze $\mathrm{Cl}^{-}, \mathrm{SO}_{4}{ }^{2-}, \mathrm{F}^{-}$and $\mathrm{Na}^{+}, \mathrm{K}^{+}, \mathrm{Ca}^{2+}, \mathrm{Mg}^{2+}, \mathrm{Li}^{+}$. Silica was analyzed using a spectrophotometric method with ammonium molybdate reagent.

\section{Analysis of non-condensable gases (NCG)}

Analysis of some NCG, i.e., $\mathrm{He}, \mathrm{H}_{2}, \mathrm{~N}_{2}, \mathrm{Ar}$, and $\mathrm{CH}_{4}$, was done using Agilent 7890A gas chromatography equipped with porapak column and thermal conductivity detector, with $\mathrm{N}_{2}$ and $\mathrm{He}$ as a carrier gas. Meanwhile, the analysis of $\mathrm{CO}_{2}$ and $\mathrm{H}_{2} \mathrm{~S}$ were conducted by using a titration method [16].

\section{- RESULTS AND DISCUSSION}

\section{Physicochemical Characteristics}

The summary of the physical properties during the dry season and rainy season are given in Table 1 and 2 .

\section{Sebau hot spring}

Sebau hot spring is located in Sapit village, Sula regency, at an elevation of $1345 \mathrm{~m}$. The temperature of the spring is $35.4{ }^{\circ} \mathrm{C}$ and neutral $\mathrm{pH}$ about 7.3 with blackish color and sulfuric odor. There is no significant change in temperature and $\mathrm{pH}$ between the rainy season and dry season. The river water was also taken as a comparison, i.e., as surface water end-member.

\section{Kalak hot spring}

Kalak hot spring is located in Sambelia area at an elevation of $1050 \mathrm{~m}$. The $\mathrm{pH}$ of the hot spring is neutral, i.e., 7.2 , while the temperature is $43.6^{\circ} \mathrm{C}$ with an ambient temperature of $23.9^{\circ} \mathrm{C}$. There is also no significant change in temperature and $\mathrm{pH}$ between the rainy season and dry season in this area.

\section{Orok warm spring and well bore}

Orok is located in Sembalun Bumbung village, Sembalun regency, at an elevation of $1219 \mathrm{~m}$. The temperature of the warm spring is $23.5^{\circ} \mathrm{C}$, and the well bore water is $23.8^{\circ} \mathrm{C}$ (at a depth of $125 \mathrm{~m}$ ) while the ambient air is $21.3^{\circ} \mathrm{C}$. The $\mathrm{pH}$ of the spring and well are neutral, i.e., 7.30 and 7.0, respectively. During the dry season, the well is dry.

\section{Rinjani hot spring}

There are some hot springs located on the slope of Mount Rinjani, i.e., Goa Susu, Rinjani-1, and Rinjani-2. Goa Susu hot spring is located at an elevation of $1891 \mathrm{~m}$, 
Table 1. Location and physical properties of springs during rainy season

\begin{tabular}{cllccccc}
\hline No. & \multicolumn{1}{c}{ Location } & Coordinate & $\begin{array}{c}\text { Elevation } \\
(\mathrm{m})\end{array}$ & $\begin{array}{c}\text { T ambient } \\
\left({ }^{\circ} \mathrm{C}\right)\end{array}$ & $\begin{array}{c}\mathrm{T} \text { sample } \\
\left({ }^{\circ} \mathrm{C}\right)\end{array}$ & pH & $\begin{array}{c}\mathrm{EC} \\
(\mathrm{mS} / \mathrm{cm})\end{array}$ \\
\hline 1 & Kalak hot spring & $\begin{array}{l}\text { S: } 9073907.93 \\
\text { E: } 454634.22\end{array}$ & 1050 & 23.9 & 43.6 & 7.20 & 2.61 \\
2 & Kalak river & $\begin{array}{l}\text { S: } 9073907.93 \\
\text { E: } 454634.22\end{array}$ & 1050 & 23.9 & 22.9 & 7.26 & 0.16 \\
3 & Sebau hot spring & $\begin{array}{l}\text { S: } 9068128.66 \\
\text { E: } 449466.36\end{array}$ & 1345 & 28.0 & 35.4 & 7.30 & 2.02 \\
4 & Sebau-1 river & $\begin{array}{l}\text { S: } 9068190.01 \\
\text { E: } 449402.07\end{array}$ & 1331 & 28.0 & 20.2 & 7.83 & 0.13 \\
5 & Orok wellbore & $\begin{array}{l}\text { S: } 9071472.94 \\
\text { E: } 449395.16\end{array}$ & 1308 & 22.4 & 23.8 & 7.00 & 0.74 \\
6 & Orok river & $\begin{array}{l}\text { S: } 9071509.79 \\
\text { E: } 449395.12\end{array}$ & 1291 & 22.4 & 20.3 & 7.00 & 0.19 \\
\hline
\end{tabular}

Table 2. Location and physical properties of springs during dry season

\begin{tabular}{|c|c|c|c|c|c|c|c|}
\hline No. & Location & Coordinate & $\begin{array}{c}\text { Elevation } \\
(\mathrm{m})\end{array}$ & $\begin{array}{c}\text { T ambient } \\
\left({ }^{\circ} \mathrm{C}\right)\end{array}$ & $\begin{array}{c}\text { T sample } \\
\left({ }^{\circ} \mathrm{C}\right)\end{array}$ & $\mathrm{pH}$ & $\begin{array}{c}\mathrm{EC} \\
(\mathrm{mS} / \mathrm{cm})\end{array}$ \\
\hline 1 & Kalak hot spring & $\begin{array}{l}\text { S: } 9073907.93 \\
\text { E: } 454634.22\end{array}$ & 1050 & 23.9 & 43.8 & 7.06 & 2.26 \\
\hline 2 & Sebau hot spring & $\begin{array}{l}\text { S: } 9068128.66 \\
\text { E: } 449466.36\end{array}$ & 1345 & 26.5 & 35.3 & 7.35 & 2.02 \\
\hline 3 & Orok warm spring & $\begin{array}{l}\text { S: } 9071509.79 \\
\text { E: } 449395.12\end{array}$ & 1291 & 21.3 & 23.5 & 7.33 & 0.80 \\
\hline 4 & Rinjani-1 hot spring & $\begin{array}{l}\text { S: } 9072534.25 \\
\text { E: } 436143.50\end{array}$ & 2003 & 18.0 & 45.0 & 6.34 & 4.03 \\
\hline 5 & Goa Susu hot spring & $\begin{array}{l}\text { S: } 9072712.26 \\
\text { E: } 436695.87\end{array}$ & 1891 & 18.0 & 42.0 & 7.00 & 3.65 \\
\hline 6 & Rinjani-2 hot spring & $\begin{array}{l}\text { S: } 9072575.80 \\
\text { E: } 436207.36\end{array}$ & 1984 & 18.0 & 44.0 & 6.22 & 5.07 \\
\hline 7 & Segara Anak lake & $\begin{array}{l}\text { S: } 9073708.56 \\
\text { E: } 450105.73\end{array}$ & 2020 & 18.0 & 20.8 & 7.94 & 3.18 \\
\hline 8 & Lemor cold spring & $\begin{array}{l}\text { S: } 9059290.29 \\
\text { E: } 452216.09\end{array}$ & 450 & 24.1 & 22.2 & 6.20 & 0.16 \\
\hline 9 & Reban cold spring & $\begin{array}{l}\text { S: } 9075893.71 \\
\text { E: } 448111.56\end{array}$ & 1297 & 22.5 & 21.2 & 8.01 & 0.20 \\
\hline 10 & Makem cold spring & $\begin{array}{l}\text { S: } 9075992.30 \\
\text { E: } 448380.59\end{array}$ & 1152 & 22.5 & 22.2 & 6.65 & 0.26 \\
\hline 11 & Jorong cold spring & $\begin{array}{l}\text { S: } 9065445.52 \\
\text { E: } 448653.11\end{array}$ & 1282 & 21.4 & 20.4 & 7.70 & 0.12 \\
\hline 12 & Rante Mas cold spring & $\begin{array}{l}\text { S: } 9073708.56 \\
\text { E: } 450105.73\end{array}$ & 1205 & 22.5 & 20.9 & 7.01 & 0.13 \\
\hline 13 & Timba Gading cold spring & $\begin{array}{l}\text { S: } 9075638.18 \\
\text { E: } 449926.74\end{array}$ & 1162 & 21.0 & 20.5 & 6.20 & 0.33 \\
\hline 14 & Sebau-1 river & $\begin{array}{l}\text { S: } 9068190.01 \\
\text { E: } 449402.07\end{array}$ & 1331 & 26.5 & 18.3 & 7.90 & 0.13 \\
\hline 15 & Sebau-2 river & $\begin{array}{l}\text { S: } 9068117.96 \\
\text { E: } 449509.18\end{array}$ & 1350 & 26.0 & 18.3 & 7.44 & 0.11 \\
\hline 16 & Orok wellbore & $\begin{array}{l}\text { S: } 9071472.94 \\
\text { E: } 449395.16\end{array}$ & 1308 & 21.3 & - & - & - \\
\hline 17 & Orok river & $\begin{array}{l}\text { S: } 9071509.79 \\
\text { E: } 449395.12\end{array}$ & 1291 & 21.3 & 20.1 & 7.76 & 0.18 \\
\hline
\end{tabular}


while Rinjani-1 and Rinjani-2 are located at an elevation of $2003 \mathrm{~m}$ and $1984 \mathrm{~m}$, respectively. The temperatures of these hot springs are $42^{\circ} \mathrm{C}, 45^{\circ} \mathrm{C}$ and $44^{\circ} \mathrm{C}$, respectively, while the ambient temperature is $18^{\circ} \mathrm{C}$. In addition, water from Segara Anak Lake (2020 m) was also taken as an endmember of meteoric water.

\section{Cold spring and river}

In addition, several cold springs and river samples were also taken as meteoric end-member. The temperature of these springs and rivers are varied at 20.2$22.2^{\circ} \mathrm{C}$, with a neutral $\mathrm{pH}$ between $6.20-8.01$.

\section{Isotopes Characteristics}

The result of stable isotope analysis $\left(\delta^{18} \mathrm{O}, \delta^{2} \mathrm{H}\right)$ during the rainy season and dry season and groundwater dating $\left({ }^{14} \mathrm{C}\right)$ can be seen in Table 3,4 , and 5 , while a graphic of $\delta^{18} \mathrm{O}$ versus $\delta^{2} \mathrm{H}$ is provided in Fig. 3. Since the Local Meteoric Water Line of Lombok is not available, the Indonesian Meteoric Water Line (IMWL) is used to help isotope data interpretation [17]. All isotope $\left(\delta^{18} \mathrm{O}\right.$ and $\left.\delta^{2} \mathrm{H}\right)$ data samples are plotted into the graph with reference to the Indonesian Meteoric Line. As a comparison, the Global Meteoric Water Line (GMWL) is also included in the graph. The isotopes $\left(\delta^{18} \mathrm{O}\right.$ and $\left.\delta^{2} \mathrm{H}\right)$ data of water samples are a representation of meteoric water, so it should be referred to the Meteoric Water Line [18].

The isotopic ratio can represent some physicalchemical processes in the geothermal system, such as water-rock interaction, mixing process, and steam separation [19]. The isotope of $\delta^{18} \mathrm{O}$ and $\delta^{2} \mathrm{H}$ are also can be used as a tracer to infer the mechanism of geothermal fluid evolution [20].

Fig. 3 shows that all cold spring and river water plotted near the Indonesia Meteoric Water Line. Meanwhile, some hot springs, i.e., Sebau, Rinjani, and Segara Anak, are plotted along the mixing line between meteoric and andesitic water. Kalak hot spring is not showing a sign of significant evaporation or oxygen shift. Orok hot spring exhibits the influence of season on isotopic composition where during the dry season shows oxygen shift and mixing with andesitic water; on the contrary, during the rainy season shows the meteoric component. In general, all hot springs in Rinjani and
Sembalun are meteoric origin with different evolution, which can be explained later by chemistry data.

Another isotope, which is used to determine the characteristics of springs in the Sembalun - Rinjani area, i.e., its age is ${ }^{14} \mathrm{C}$ radioisotope. The result of ${ }^{14} \mathrm{C}$ analysis is expressed in units of percent Modern Carbon (pMC)

Table 3. Result of stable isotope analysis $\left(\delta^{18} \mathrm{O}\right.$ and $\left.\delta^{2} \mathrm{H}\right)$ during the rainy season

\begin{tabular}{clcc}
\hline No. & \multicolumn{1}{c}{ Location } & $\delta^{18} \mathrm{O}(\% \mathrm{o})$ & $\delta^{2} \mathrm{H}(\% \mathrm{o})$ \\
\hline 1 & Kalak hot spring & -6.87 & -49.76 \\
2 & Sebau hot spring & -5.41 & -42.72 \\
3 & Orok well bore & -7.63 & -48.38 \\
4 & Kalak river & -6.45 & -45.84 \\
5 & Sebau river & -7.64 & -45.90 \\
6 & Orok river & -6.36 & -46.99 \\
\hline
\end{tabular}

Table 4. Result of stable isotope analysis $\left(\delta^{18} \mathrm{O}\right.$ and $\left.\delta^{2} \mathrm{H}\right)$ during the dry season

\begin{tabular}{clcc}
\hline No. & \multicolumn{1}{c}{ Location } & $\delta^{18} \mathrm{O}(\% \mathrm{o})$ & $\delta^{2} \mathrm{H}(\% \mathrm{o})$ \\
\hline 1 & Kalak hot spring & -6.62 & -49.30 \\
2 & Sebau hot spring & -5.50 & -41.40 \\
3 & Orok warm spring & -5.59 & -46.30 \\
4 & Rinjani-1 hot spring & -2.09 & -34.10 \\
5 & Goa Susu hot spring & -3.65 & -38.00 \\
6 & Rinjani-2 hot spring & -3.58 & -38.10 \\
7 & Segara Anak lake & -1.96 & -34.80 \\
8 & Lemor spring & -5.50 & -35.50 \\
9 & Reban spring & -7.09 & -47.30 \\
10 & Makom spring & -7.04 & -46.90 \\
11 & Jorong spring & -6.73 & -45.10 \\
12 & Rante Mas spring & -6.95 & -48.80 \\
13 & Timba Gading spring & -6.58 & -42.50 \\
14 & Sebau-1 river & -6.75 & -43.70 \\
15 & Sebau-2 river & -6.58 & -44.30 \\
16 & Orok river & -6.77 & -47.00 \\
\hline
\end{tabular}

Table 5. Analysis result of ${ }^{14} \mathrm{C}$ dating in Sembalun area

\begin{tabular}{lcc}
\hline \multicolumn{1}{c}{ Location } & pMC & Age (years BP) \\
\hline Kalak hot spring & 26.95 & 10,425 \\
Sebau hot spring & 22.18 & 12,030 \\
Orok warm spring & 24.41 & 11,240 \\
Jorong cold spring & 42.20 & 6,715 \\
Timba Gading cold spring & 93.50 & 140 \\
Lemor cold spring & 93.52 & 135 \\
\hline
\end{tabular}




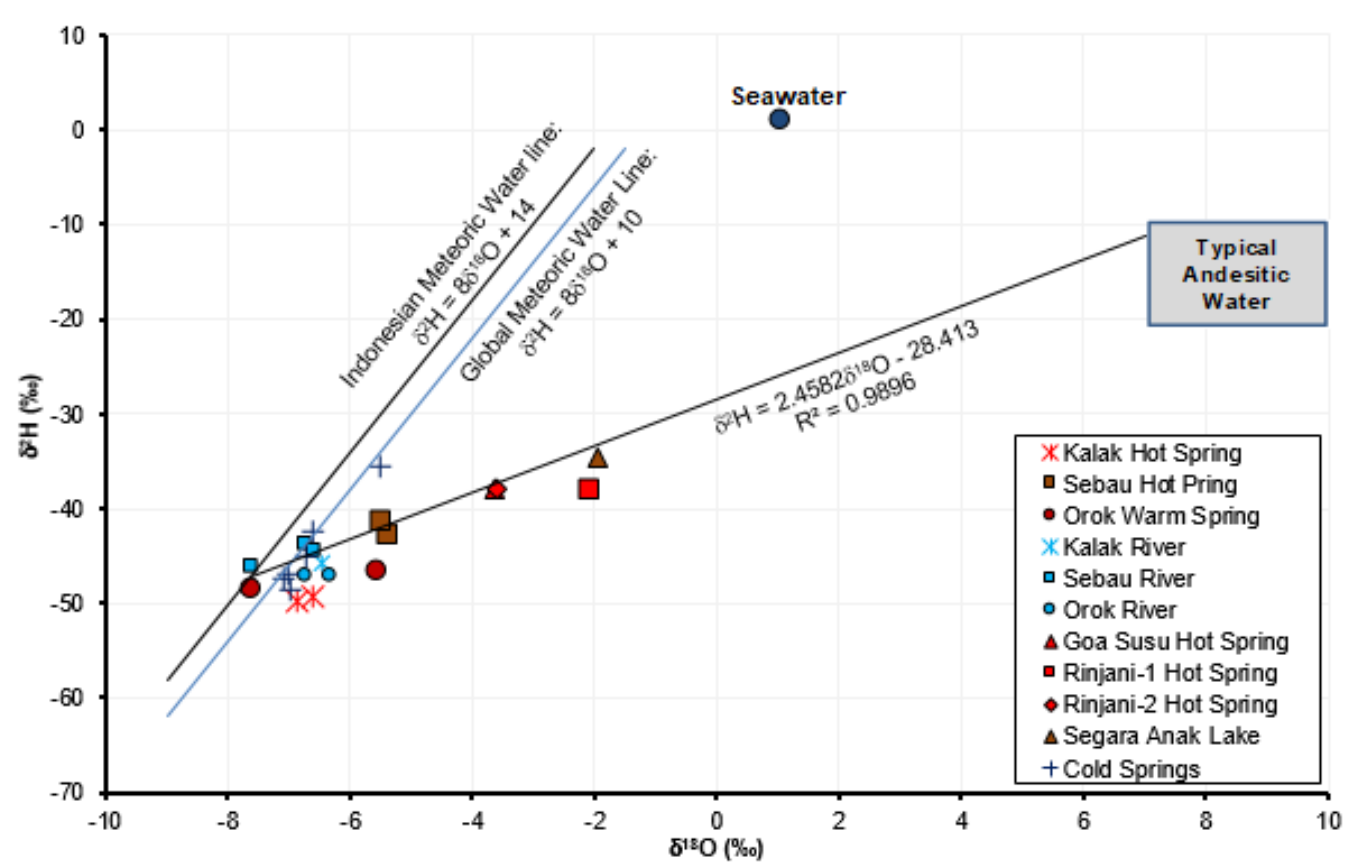

Fig 3. Graphic of $\delta^{2} \mathrm{H}$ vs. $\delta^{18} \mathrm{O}$ of the hot and cold spring in Sembalun - Rinjani area

and then converted into age (years BP) with the following equation [21]:

$\mathrm{t}=8267 \ln \left(\frac{100}{\mathrm{~A}_{\mathrm{SN}}}\right)$

where, $\mathrm{A}_{\mathrm{SN}}=$ the radioisotope ${ }^{14} \mathrm{C}$ activity of the sample $(\mathrm{pMC}) ; \mathrm{t}=$ year BP (before present $=$ before 1950)

The result of a radioisotope of ${ }^{14} \mathrm{C}$ (groundwater dating) shows that Sebau, Kalak, and Orok hot springs have relatively the same age between 10,000-12,000 year $\mathrm{BP}$, where Kalak hot spring is younger than two other hot springs. This probably due to mixing with local shallow groundwater. Jorong cold spring is 6,751 years BP, which probably comes from the upper hillside, while Timba Gading and Lemor cold springs are young groundwater below 200 years BP. The information on groundwater age is important because the sustainability of geothermal exploitation depends on fluid presence.

\section{Geothermal fluid fraction}

The fraction of geothermal fluid can be calculated using the following equation [22-23]:

$\delta_{\mathrm{m}} \mathrm{O}^{18}=\delta_{\mathrm{aw}} \mathrm{O}^{18} \cdot \mathrm{x}-\delta_{\mathrm{rw}} \mathrm{O}^{18} \cdot(1-\mathrm{x})$

where $\mathrm{x}=$ fraction of andesitic water; $\delta_{\mathrm{m}} \mathrm{O}^{18}={ }^{18} \mathrm{O}$ composition of mixed groundwater and andesitic water $(\%) ; \delta_{\mathrm{aw}} \mathrm{O}^{18}={ }^{18} \mathrm{O}$ composition of andesitic water $(\%)$;
Table 6. Fraction of fluid from hot springs at Sembalun - Rinjani area

\begin{tabular}{llcc}
\hline No. & Location & $\begin{array}{c}\text { Andesitic } \\
\text { Water }\end{array}$ & $\begin{array}{c}\text { Meteoric } \\
\text { Water }\end{array}$ \\
\hline \multicolumn{2}{c}{ Rainy season } \\
1 & Sebau hot spring & 0.14 & 0.86 \\
2 & Orok wellbore & 0.00 & 1.00 \\
Dry season & & \\
$1 \quad$ Sebau hot spring & 0.13 & 0.87 \\
2 & Rinjani-1 hot spring & 0.35 & 0.65 \\
3 & Goa Susu hot spring & 0.25 & 0.75 \\
4 & Rinjani-2 hot spring & 0.26 & 0.74 \\
5 & Segara Anak lake & 0.36 & 0.64 \\
\hline
\end{tabular}

$\delta_{\mathrm{rw}} \mathrm{O}^{18}={ }^{18} \mathrm{O}$ composition of groundwater $(\%)$

Table 6 shows the calculated geothermal fluid fraction from several hot springs in the Rinjani Sembalun area. Generally, the geothermal fluid of Sembalun - Rinjani is dominated by meteoric water, where at Sebau meteoric water fraction is consistent during the rainy and dry season, i.e., $86-87 \%$. Meanwhile, hot springs at Rinjani hillside and Segara Anak, the fraction of meteoric water is lesser, i.e., 64-75\%.

\section{Chemical Characteristics}

The results of the chemical analysis of hot springs, cold springs, and river water samples in the Sembalun - 
Rinjani area, West Nusa Tenggara, which were taken in two seasons, rain and dry, can be seen in Table 7 and 8 .

\section{Fluid characteristics}

Table 7 and 8 show that hot springs are distinguished from cold springs (MAD) from its TDS, i.e., hot springs have higher TDS than cold springs. However, there are differences between the hot springs, i.e., its chloride and sulfate content. Kalak has lower chloride content than Sebau hot spring, i.e., $173 \mathrm{mg} / \mathrm{L}$ and $526 \mathrm{mg} / \mathrm{L}$, respectively. On the contrary, sulfate content of Kalak is much higher than Sebau, i.e., $1114 \mathrm{mg} / \mathrm{L}$ and $78.1 \mathrm{mg} / \mathrm{L}$, respectively, which also consistent with the previous study by Sundhoro et al. [24]. This difference can be seen clearly by a ternary diagram of $\mathrm{Cl}-\mathrm{SO}_{4}-\mathrm{HCO}_{3}$ (Fig. 4), which also depicts the hydrochemistry classification of the hot springs.

From the diagram, it can be seen that Sebau hot spring is plotted closer to mature water or reservoir composition due to its dominant chloride; however, this is not the case. Sebau hot spring is high in Mg content, which infer more dominant groundwater end-member [25]. Meanwhile, Kalak hot spring is plotted at the sulfate corner, but it is not steam-heated water due to its neutral $\mathrm{pH}$. Moreover, there is no steam vent or fumarole around Kalak hot spring. Thus, the high sulfate content in Kalak is not originated from geothermal $\mathrm{H}_{2} \mathrm{~S}$ oxidation but likely caused by leaching from a sulfurbearing rock formation. Orok warm spring is plotted on

Table 7. Chemical composition (mg/L) during rainy season

\begin{tabular}{clcccccccccc}
\hline \multirow{2}{*}{ No. } & Location & \multicolumn{4}{c}{ Cation } & \multicolumn{4}{c}{ Anion } \\
\cline { 2 - 12 } & $\mathrm{K}$ & $\mathrm{Na}$ & $\mathrm{Ca}$ & $\mathrm{Mg}$ & $\mathrm{SiO}_{2}$ & $\mathrm{Cl}$ & $\mathrm{SO}_{4}$ & $\mathrm{~F}$ & $\mathrm{HCO}_{3}$ & $\mathrm{~B}$ \\
\hline 1 & Kalak hot spring & 4.87 & 255.25 & 425.37 & 3.78 & 45.71 & 173.42 & 1114.52 & 0.47 & 147.46 & 2.13 \\
2 & Sebau hot spring & 5.90 & 178.25 & 174.01 & 1.31 & 32.96 & 526.22 & 78.09 & 0.36 & 90.55 & 3.39 \\
3 & Orok well bore & 11.50 & 88.10 & 93.25 & 48.17 & 54.09 & 34.44 & 81.37 & 0.28 & 550.66 & 1.10 \\
4 & Kalak river & 3.86 & 8.54 & 32.25 & 8.76 & 38.05 & 3.02 & 11.64 & 0.14 & 128.66 & n.d. \\
5 & Sebau river & 1.41 & 5.16 & 16.97 & 7.59 & 27.37 & 3.49 & 5.57 & 0.15 & 115.29 & n.d. \\
6 & Orok river & 4.33 & 10.61 & 24.44 & 12.83 & 38.88 & 2.00 & 16.72 & 0.19 & 175.33 & n.d. \\
\hline n.d.: not detected & & & & & & & & & &
\end{tabular}

Table 8. Chemical composition (mg/L) during dry season

\begin{tabular}{clcccccccccc}
\hline \multirow{2}{*}{ No. } & \multicolumn{1}{c}{ Location } & \multicolumn{4}{c}{ Cation } & \multicolumn{5}{c}{ Anion } \\
\cline { 2 - 12 } & & $\mathrm{K}$ & $\mathrm{Na}$ & $\mathrm{Ca}$ & $\mathrm{Mg}$ & $\mathrm{SiO}_{2}$ & $\mathrm{Cl}$ & $\mathrm{SO}_{4}$ & $\mathrm{~F}$ & $\mathrm{HCO}_{3}$ & $\mathrm{~B}$ \\
\hline 1 & Kalak hot spring & 3.45 & 164.42 & 216.02 & 13.67 & 60.05 & 109.06 & 811.92 & 0.34 & 141.38 & 1.85 \\
2 & Sebau hot spring & 6.48 & 170.91 & 291.88 & 11.21 & 40.69 & 627.10 & 14.29 & 0.21 & 136.5 & 3.59 \\
3 & Orok hot spring & 3.24 & 72.27 & 45.16 & 43.29 & 66.73 & 89.23 & 101.05 & 0.33 & 338.7 & 2.16 \\
4 & Rinjani-1 hot spring & 49.67 & 357.95 & 388.66 & 362.91 & 120.08 & 470.89 & 2254.19 & 0.53 & 316.88 & 5.67 \\
5 & Goa Susu hot spring & 47.77 & 346.11 & 215.72 & 31.63 & 144.34 & 477.02 & 313.62 & 0.50 & 782.34 & 6.12 \\
6 & Rinjani-2 hot spring & 49.46 & 384.39 & 189.46 & 348.70 & 131.48 & 530.54 & 1028.21 & 0.69 & 1145.65 & 5.52 \\
7 & Segara Anak lake (DSA) & 45.36 & 282.80 & 121.68 & 337.94 & 89.98 & 470.89 & 1033.63 & 1.53 & 582.58 & 3.43 \\
8 & Lemor cold spring & 3.5 & 5.02 & 16.43 & 13.28 & 57.61 & 3.22 & 6.98 & 0.41 & 117.47 & n.d. \\
9 & Reban cold spring & 3.83 & 6.27 & 12.38 & 15.19 & 53.20 & 5.28 & 9.36 & 0.48 & 130.38 & 0.11 \\
10 & Makom cold spring & 8.19 & 10.98 & 14.83 & 14.76 & 53.87 & 3.34 & 17.75 & 0.6 & 152.82 & n.d. \\
11 & Jorong cold spring & 3.26 & 4.39 & 10.96 & 9.95 & 49.80 & 2.07 & n.d. & 0.57 & 110.88 & 0.18 \\
12 & Rante Mas cold spring & 2.31 & 3.24 & 10.74 & 5.73 & 44.90 & 1.99 & 3.98 & 0.14 & 74.82 & n.d. \\
13 & Timba Gading spring & 7.90 & 17.36 & 25.05 & 27.63 & 59.39 & 8.59 & 23.7 & 0.61 & 202.26 & 0.1 \\
14 & Sebau-1 river & 1.49 & 10.62 & 27.54 & 10.01 & 37.42 & 15.78 & 33.23 & 0.13 & 124.32 & 0.18 \\
15 & Sebau-2 river & 2.61 & 3.27 & 15.87 & 8.23 & 34.66 & 1.11 & 15.8 & 0.12 & 99.44 & n.d \\
16 & Orok river & 2.93 & 4.12 & 27.13 & 13.39 & 62.17 & 1.54 & 32.1 & 0.2 & 122.82 & n.d \\
\hline n.d.: not detected & & & & & & & & & &
\end{tabular}


bicarbonate corner clearly shows mixing with groundwater, as also indicated by its near ambient temperature. Rinjani hot springs are plotted spreading between sulfate and bicarbonate, while cold springs are plotted at bicarbonate corner.

The different characteristics between hot springs can be assessed by correlation graphs between $\mathrm{Na}$ vs. $\mathrm{Cl}$ and $\mathrm{Na}$ vs. $\mathrm{SO}_{4}$ (Fig. 5).

Fig. 5 shows that there is no common linear relationship between $\mathrm{Na}$ and $\mathrm{Cl}$ of all hot springs but rather divided into three groups: Sebau-Orok, Rinjani, and Kalak groups. Meanwhile, the graph of $\mathrm{Na}$ vs. $\mathrm{SO}_{4}$ shows a more random plot that indicates different genesis of fluids since $\mathrm{SO}_{4}$ is not a conservative element. Thus, the $\mathrm{SO}_{4}$ concentration is more likely influenced by rock mineral composition. On the other hand, Segara Anak shows unique chemical composition, i.e., high $\mathrm{Cl}$ and $\mathrm{SO}_{4}$ concentration but with neutral $\mathrm{pH}$, which is different from the typical volcanic lake that has high $\mathrm{Cl}$ and $\mathrm{SO}_{4}$ concentration but with low $\mathrm{pH}$ as Kawah Ijen volcanic lake [26]. There are two possibilities of Segara Anak fluid genesis: (1) the fluid is the hydrothermal origin with high $\mathrm{Cl}$ content, leaching out sulfate from rocks, and later mixing with meteoric water, (2) Input of magmatic gas, neutralized during fluid-rock interaction and later mixing with meteoric water.

\section{Origin of fluids}

The fluid origin also can be inferred from $\mathrm{Li}-\mathrm{Cl}-\mathrm{B}$ ternary diagram (Fig. 6). The diagram shows that none of

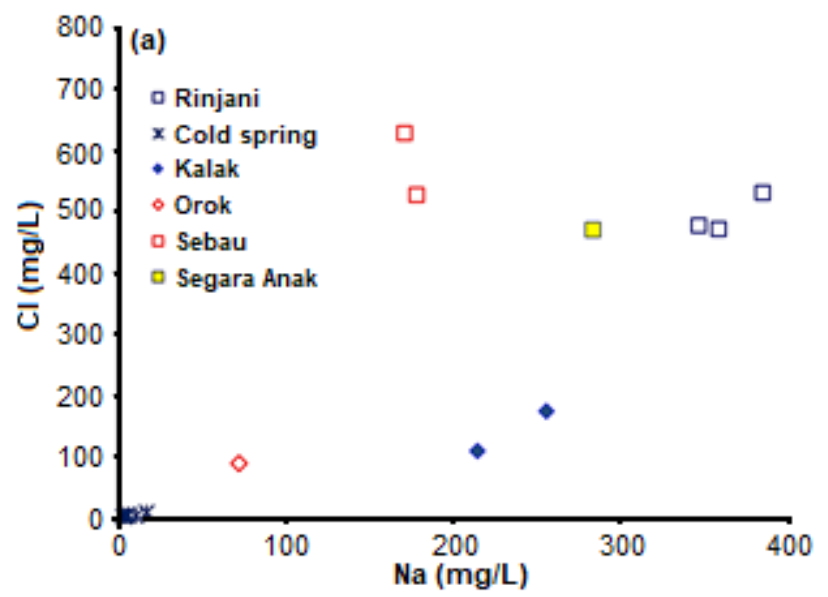

Fig 5. Correlation plot between: (a) $\mathrm{Na}$ vs. $\mathrm{Cl}$ and (b) $\mathrm{Na}$ vs. $\mathrm{SO}_{4}$ the hot springs is plotted near the Li corner, indicates dominant deep rock dissolution [27], while springs plotted near $\mathrm{Cl}$ corner are originated from absorption of low $\mathrm{B} / \mathrm{Cl}$ steam.

\section{Geothermometer}

Estimation of reservoir temperature is based on temperature-dependent of specific equilibration reaction, i.e., isotopes, cation solubility, and gases, applied to the composition of discharge geothermal fluids, i.e., hot springs, production wells, fumaroles [28]. In this study, $\mathrm{Na} / \mathrm{K}$ and $\mathrm{SiO}_{2}$ geothermometer are applied to estimate reservoir temperature (Table 9) [29].

Based on $\mathrm{Na} / \mathrm{K}$ geothermometer, subsurface temperature from Kalak hot spring is estimated at about $111-126^{\circ} \mathrm{C}$, while Sebau hot spring is higher around

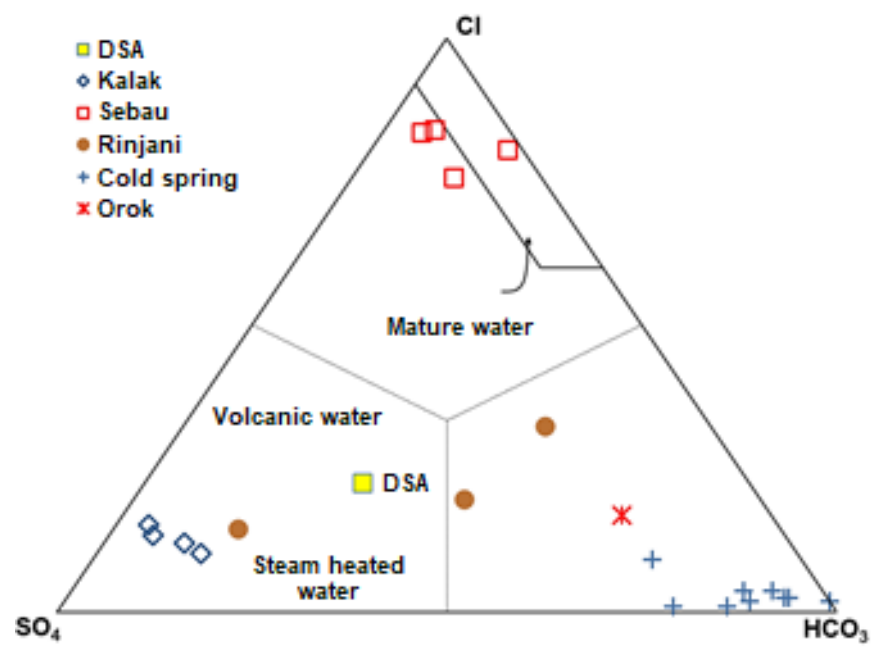

Fig 4. Ternary diagram of $\mathrm{Cl}-\mathrm{SO}_{4}-\mathrm{HCO}_{3}$

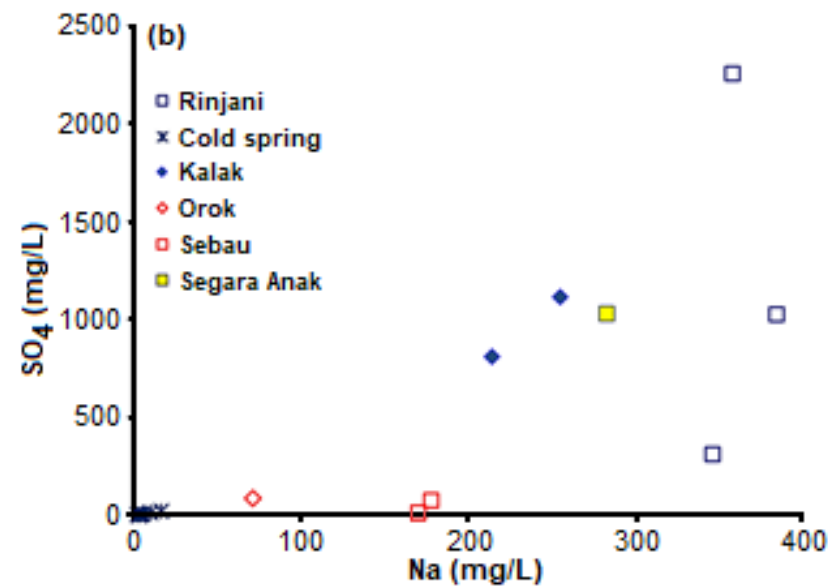




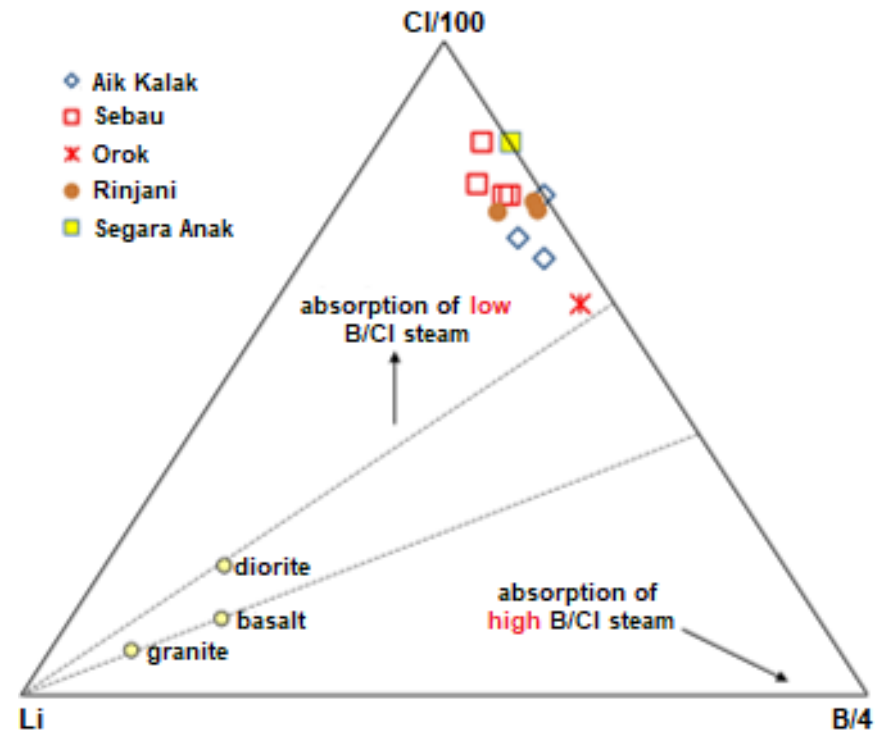

Fig 6. Ternary diagram of Li-Cl-B

$148-161{ }^{\circ} \mathrm{C}$. Rinjani hot spring indicates the highest reservoir temperature, i.e., $250-260{ }^{\circ} \mathrm{C}$. Giggenbach ternary diagram (Fig. 7) shows that Kalak and Sebau hot springs are plotted at immature water composition where reservoir fluid is mixed with shallow water [30]. Calculation of silica quartz geothermometer indicates lower temperature, i.e., $98{ }^{\circ} \mathrm{C}$, and $83{ }^{\circ} \mathrm{C}$ for Kalak, and Sebau hot springs, respectively. This low temperature is due to the fact that silica has a faster equilibrium rate compare to $\mathrm{Na} / \mathrm{K}$ equilibrium; thus, this silica geothermometer indicates equilibrium temperature at shallower aquifer or mixing with aquifer with low silica content [31].

\section{Gas composition}

Relative composition of $\mathrm{He}, \mathrm{Ar}$, and $\mathrm{N}_{2}$ can be utilized to distinguish the origin of volcanic and geothermal gases [32], i.e., meteoric, andesitic, or crustal origin [33]. Table 10 shows gas composition taken from bubbling pool at mount Rinjani slope. NCG (noncondensable gases) content is relatively high, i.e., $66 \% \mathrm{~mol}$. Meanwhile, $\mathrm{CO}_{2}$ and $\mathrm{H}_{2} \mathrm{~S}$ are dominant gases, reaching $90 \% \mathrm{~mol}$ and $8.6 \% \mathrm{~mol}$ from total NCG, respectively. This composition is slightly different from typical geothermal gas composition, where $\mathrm{H}_{2} \mathrm{~S}$ content is up to $15 \%$ [34]. This is possibly due to the conversion of $\mathrm{H}_{2} \mathrm{~S}$ into $\mathrm{SO}_{4}$ by

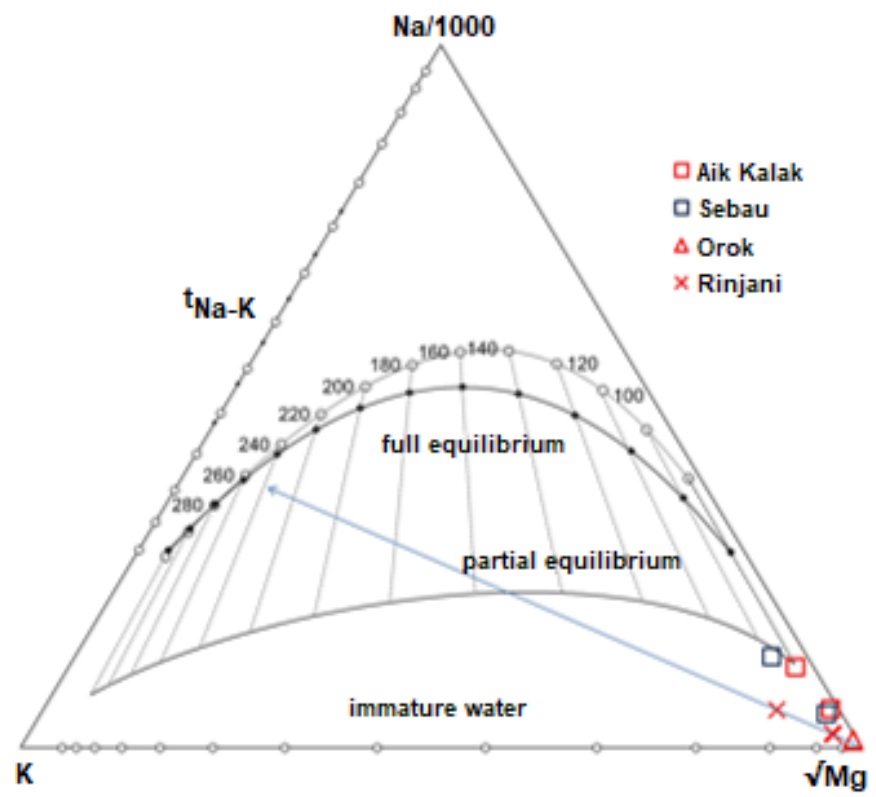

Fig 7. Giggenbach ternary diagram

Table 9. Calculation of $\mathrm{Na} / \mathrm{K}$ and $\mathrm{SiO}_{2}$ geothermometer

\begin{tabular}{|c|c|c|c|c|}
\hline \multirow[b]{2}{*}{ Location } & & \multicolumn{3}{|c|}{ Geothermometer $\left({ }^{\circ} \mathrm{C}\right)$} \\
\hline & & $\mathrm{Na} / \mathrm{K}$ Fournier & $\mathrm{Na} / \mathrm{K}$ GGB & $\mathrm{SiO}_{2}$ Quartz \\
\hline Kalak hot spring (rainy season) & & 112 & 127 & 98 \\
\hline \multirow[t]{2}{*}{ Kalak hot spring (dry season) } & & 109 & 124 & 111 \\
\hline & Average & 111 & 126 & 105 \\
\hline Sebau hot spring (rainy season) & & 144 & 157 & 83 \\
\hline \multirow[t]{2}{*}{ Sebau hot spring (dry season) } & & 152 & 165 & 92 \\
\hline & Average & 148 & 161 & 88 \\
\hline Orok hot spring & & 164 & 175 & 116 \\
\hline Rinjani-1 hot spring & & 257 & 260 & 148 \\
\hline Goa Susu hot spring & & 256 & 259 & 159 \\
\hline Rinjani-2 hot spring & & 250 & 253 & 153 \\
\hline
\end{tabular}


Table 10. Gas composition of Rinjani-2

\begin{tabular}{ccccccccc}
\hline & \multicolumn{7}{c}{$\mathrm{mmol}$} \\
\hline $\mathrm{CO}_{2}$ & $\mathrm{H}_{2} \mathrm{~S}$ & $\mathrm{He}$ & $\mathrm{H}_{2}$ & $\mathrm{~N}_{2}$ & $\mathrm{O}_{2}$ & $\mathrm{Ar}$ & $\mathrm{CH}_{4}$ & steam \\
\hline 95.667 & 1.011 & 0.0013 & $\mathrm{Ttd}$ & 9.2036 & $\mathrm{Ttd}$ & 0.1941 & 0.0682 & 54.43 \\
\hline & & & & $\% \mathrm{~mol}$ & & & & \\
\hline $\mathrm{CO}_{2}$ & $\mathrm{H}_{2} \mathrm{~S}$ & $\mathrm{He}$ & $\mathrm{H}_{2}$ & $\mathrm{~N}_{2}$ & $\mathrm{O}_{2}$ & $\mathrm{Ar}$ & $\mathrm{CH}_{4}$ & total NCG \\
\hline 90.13 & 0.95 & 0.00 & $\mathrm{Ttd}$ & 8.67 & $\mathrm{Ttd}$ & 0.18 & 0.06 & 66.10 \\
\hline
\end{tabular}

oxidation, as can be seen in $\mathrm{SO}_{4}$ content of Rinjani hot spring [35].

The ratio of $\mathrm{N}_{2} / \mathrm{Ar}$ is 47 , which indicates that the fluid origin is meteoric, as also can be seen in the $\mathrm{He}-\mathrm{N}_{2}-$ Ar ternary diagram (Fig. 8).

\section{Reservoir fluid composition (mixing model)}

Discharged fluid at hot springs is already altered from its reservoir composition due to physical-chemical interaction during ascending to surface. The actual reservoir composition, i.e., chloride and silica, can be estimated and traceback using silica-enthalpy and chloride-enthalpy mixing models [36], as can be seen in Fig. 9, which shows the curve of the quartzgeothermometer. It also shows that the mixing line is only passing through Orok and Rinjani samples and then intercept the curve at $450 \mathrm{mg} / \mathrm{L}$ silica and enthalpy of $850 \mathrm{~kJ} / \mathrm{kg}$, which is equivalent to $218^{\circ} \mathrm{C}$. Sebau and Kalak are not connected through the mixing line because the relation between silica and chloride in both samples is not positively correlated (Fig. 10), i.e., loss of silica from the

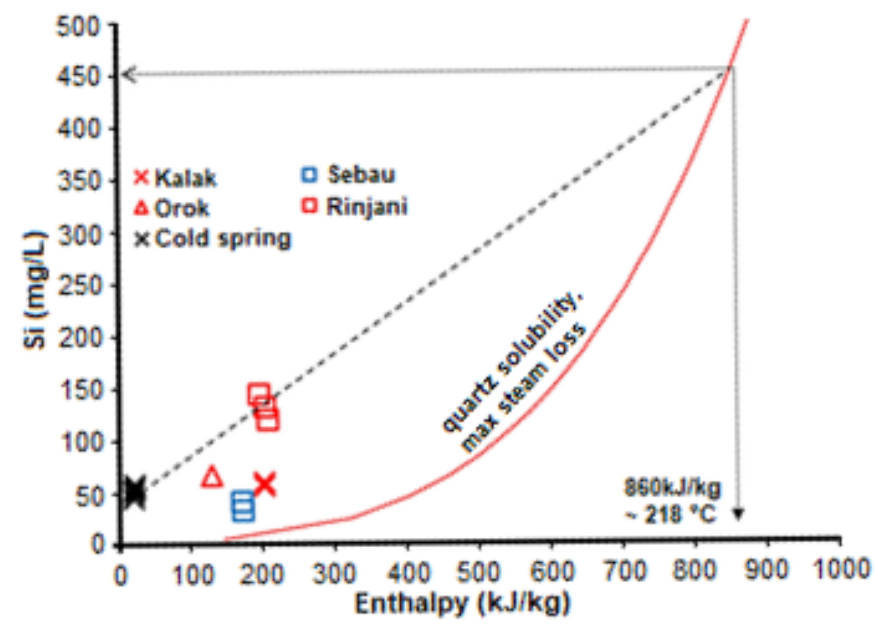

Fig 9. Mixing model of silica vs. enthalpy fluid due to forming of secondary mineral [37-38]. Based on enthalpy of the reservoir, the composition of the reservoir's chloride can be estimated using the chlorideenthalpy diagram (Fig. 11). It is shown that the mixing

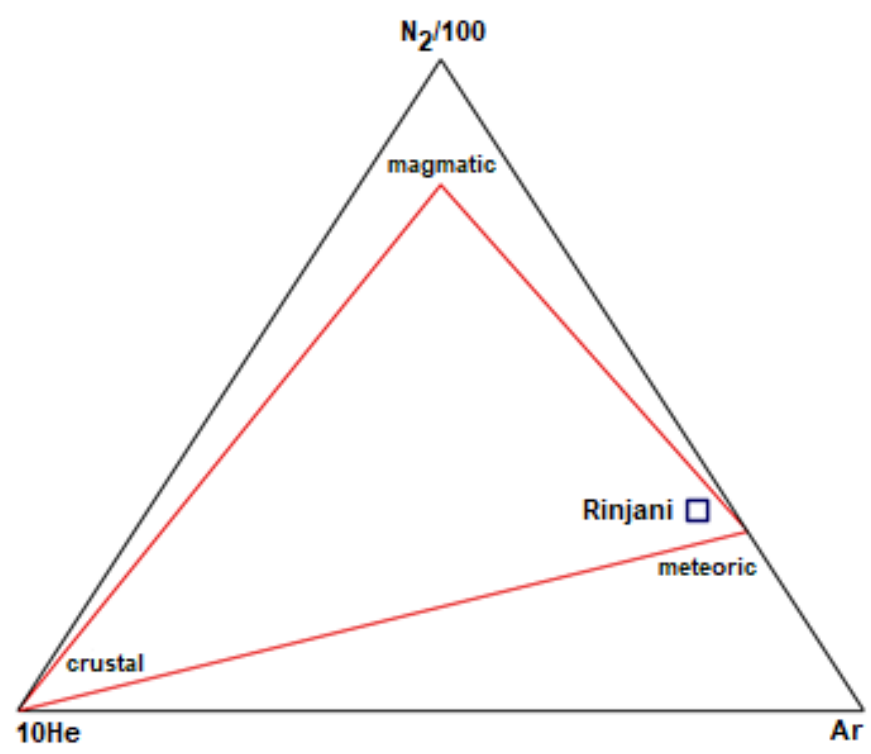

Fig 8. Ternary diagram of $\mathrm{He}-\mathrm{N}_{2}-\mathrm{Ar}$

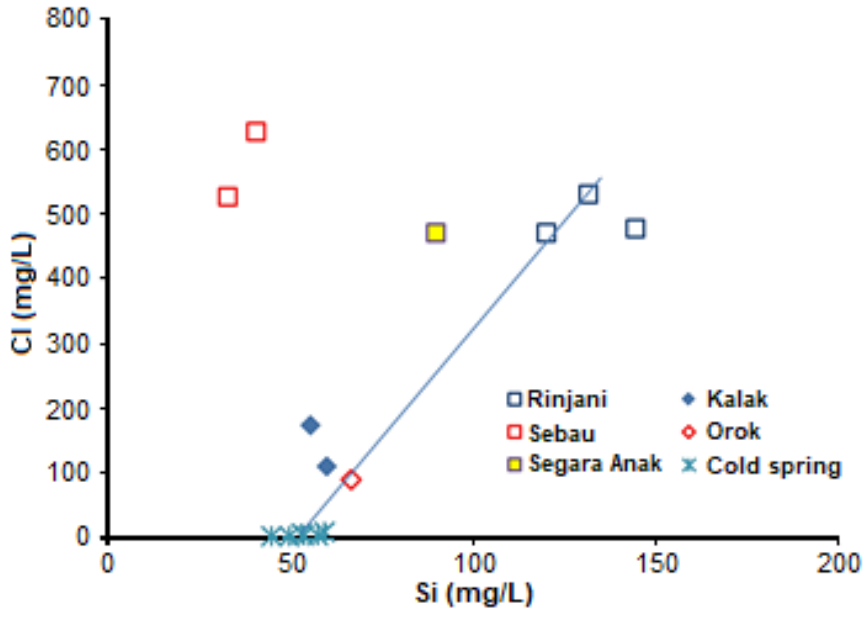

Fig 10. Correlation diagram of silica vs. chloride 


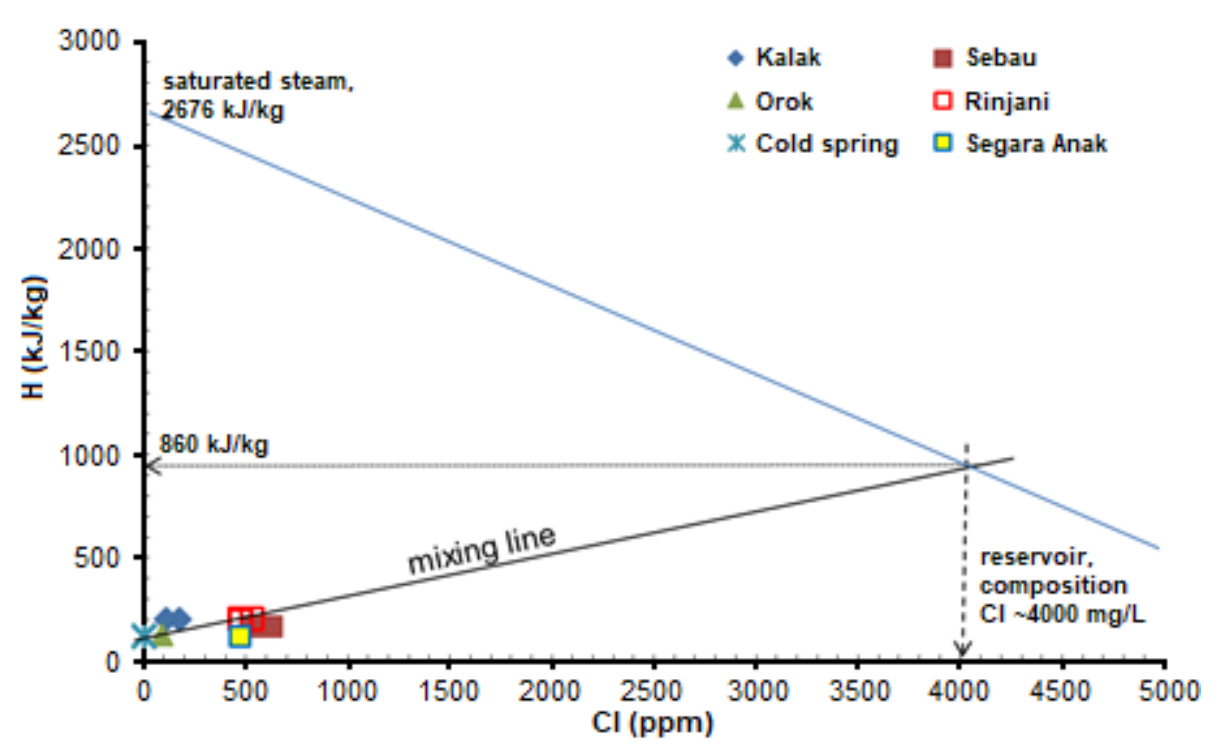

Fig 11. Mixing model of $\mathrm{Cl}$ vs. enthalpy

line with groundwater intercepts at enthalpy of $850 \mathrm{~kJ} / \mathrm{kg}$ and chloride concentration at $40000 \mathrm{ppm}$, i.e., chloride concentration in the reservoir.

\section{- CONCLUSION}

Based on stable isotopes content $\left(\delta^{18} \mathrm{O}, \delta^{2} \mathrm{H}\right)$, it is found that all hot springs except Kalak, are the product of mixing between meteoric water and andesitic water with meteoric fraction about 0.64-0.87, while other surrounding springs are clearly meteoric water. Gas content, i.e., $\mathrm{He}, \mathrm{Ar}, \mathrm{N}_{2}$, also indicates that fluid origin is meteoric water. The ${ }^{14} \mathrm{C}$ dating of Kalak hot spring shows 10,425 years BP of age. Sebau and Orok hot springs have an older groundwater age than Kalak hot spring, i.e. 12,030 years BP and 11,240 years BP, respectively, while surrounding cold springs are mostly modern except Jorong cold spring. Although Kalak hot spring is plotted on the sulfate corner, it does not have acidic properties; thus, it is not steam-heated waters. The high sulfate content in Kalak is not coming from $\mathrm{H}_{2} \mathrm{~S}$ oxidation but probably caused by leaching of sulfur-bearing minerals. Although Sebau hot spring is plotted at mature water composition with dominant chloride content, the hot spring does not represent reservoir fluid considering its low temperature and high $\mathrm{Mg}$ content.

Based on $\mathrm{Na} / \mathrm{K}$ geothermometer, subsurface temperature for Kalak is estimated between $111-126^{\circ} \mathrm{C}$, while for Sebau is higher, i.e., between $148-161{ }^{\circ} \mathrm{C}$. The highest temperature estimation is found in Rinjani, i.e. $250-260{ }^{\circ} \mathrm{C}$. The geothermal fluid of the Sembalun area is calculated having brine composition with chloride content about $4000 \mathrm{mg} / \mathrm{L}$, thus scaling can be a potential problem in the future.

\section{- REFERENCES}

[1] Sundhoro, H., Kasbani, Yushantarti, A., and Hadi, M.N., 2007, Penyelidikan geologi dan geokimia daerah panas bumi Sembalun, Kabupaten Lombok Timur - Nusa Tenggara Barat, Proceeding Pemaparan Hasil Kegiatan Lapangan dan Non Lapangan Tahun 2007, Pusat Sumber Daya Geology, 1-7.

[2] Chenaker, H., Houha, B., and Valles, V., 2017, Isotope studies and chemical investigations of hot springs from North-Eastern Algeria, J. Mater. Environ. Sci., 8 (12), 4253-4263.

[3] Mwangi, S.M., 2013, Application of geochemical methods in geothermal exploration in Kenya, Procedia Earth Planet. Sci., 7, 602-606.

[4] Cabrera, A., Blarasin, M., and Maldonado, L., 2017, Groundwater age and hydrothermalism of confined aquifers in the Argentine Pampean plain, Geotherm. Energy, 5, 6.

[5] Bouchaou, L., Warner, N.R., Tagma, T., Hssaisoune, M., and Vengosh, V., 2017, The origin 
of geothermal waters in Morocco: Multiple isotope tracers for delineating sources of water-rock interactions, Appl. Geochem., 84, 244-253.

[6] Hou, Y., Shi, Z., and Mu, W., 2018, Fluid geochemistry of fault zone hydrothermal system in the Yidun-Litang area, eastern Tibetan Plateau geothermal belt, Geofluids, 2018, 6872563.

[7] Hadi, M.N., Yushantarti, A., Suhanto, E., and Sundhoro, H., 2007, Survei panas bumi terpadu (geologi, geokimia dan geofisika) daerah Sembalun, Kabupaten Lombok Timur - NTB, Proceeding Pemaparan Hasil Kegiatan Lapangan dan Non Lapangan Tahun 2007, Pusat Sumber Daya Geology, 1-14.

[8] Clark, I.D., and Fritz, P., 1997, Environmental Isotopes in Hydrogeology, CRC Press, Boca Raton, Florida, 285.

[9] Wijatna, A.B., Kayyis, M., Satrio, and Pujiindiyati, E.R., 2019, Study of seawater intrusion in deep aquifers of Semarang coast using natural isotopes and hydrochemical, Indones. J. Geosci., 6 (1), 17-28.

[10] Aggarwal, P.K., Araguas-Araguas, L., Choudhry, M., van Duren, M., and Froehlich, K., 2013, Lower groundwater ${ }^{14} \mathrm{C}$ age by atmospheric $\mathrm{CO}_{2}$ uptake during sampling and analysis, Groundwater, 52 (1), 20-24.

[11] Joseph, E.P., Fournier, N., Lindsay, J.M., Robertson, R., and Beckles, D.M., 2013, Chemical and isotopic characteristics of geothermal fluids from Sulphur Springs, Saint Lucia, J. Volcanol. Geotherm. Res., 254, 23-36.

[12] Marini, L., 2000, Geochemical techniques for the exploration and exploitation of geothermal energy, Department for the Study of Territory and its Resources, University of Genoa, Corso Europa 26, 16132, Genoa, Italy, 1-82.

[13] Muhammad, S.B., and Sadiq, U., 2014, Analysis of stable isotopic composition of precipitation in Katsina State in Nigeria as an indication of water cycle, Adv. Phys. Theor. Appl., 33, 28-34.

[14] Hendriksson, N., Karhu, J., and Niinikoski, P., 2014, ${ }^{18} \mathrm{O},{ }^{2} \mathrm{H}$ and ${ }^{3} \mathrm{H}$ Isotopic Composition of Precipitation and Shallow Groundwater in Olkiluoto, Working
Report 2014-69, Posiva Oy, FI-27160 Eurajoki, Finland, 1-48.

[15] Canducci, C., Bartolomei, P., Magnani, G., Rizzo, A., Piccoli, A., Tositti, L., and Esposito, M., 2013, Upgrade of the $\mathrm{CO}_{2}$ direct absorption method for low-level ${ }^{14} \mathrm{C}$ liquid scintillation counting, Radiocarbon, 55 (2), 260-67.

[16] Armannsson, H., and Olafsson, M., 2007, Geothermal sampling and analysis, Short Course II on Surface Exploration for Geothermal Resources, UNU-GTP and KenGen, Lake Naivasha, Kenya, 217 November 2007, 1-8.

[17] Bungkus, P., and Satrio, 2014, Garis meterorik Indonesia, Prosiding Seminar Nasional Geologi untuk Meningkatkan Kesejahteraan Masyarakat, Faculty of Geological Engineering, Universitas Padjadjaran, Bandung, 24 May 2014.

[18] Geyh, M., 2000, Environmental Isotopes in the Hydrological Cycle: Principles and Applications, Volume IV. Groundwater - Saturated and Unsaturated Zone, Eds. Mook, W.G., International Hydrological Programme, UNESCO/IAEA Series.

[19] Güleç, N., 2013, "Isotope and gas geochemistry of geothermal systems" in Geothermal Exploration Best Practices - Geology, Exploration Drilling, Geochemistry, Geophysics, Eds. Bracke, R., Harvey, C., and Rueter, H., IGA Academy Report, Bochum, Germany, 0112-2013.

[20] Arvanitis, A., Dotsika, E., and Kolios, N., 2016, Geochemical characteristics of the geothermal fluids in the Akropotamos area (Macedonia, Northern Greece), BGSG, 50 (2), 596-605.

[21] IAEA, 2013, Isotope Methods for Dating Old Groundwater, International Atomic energy Agency, Vienna, Austria, 39-40.

[22] Porowski, A., 2014, "Isotope hydrogeology" in Handbook of Engineering Hydrology: Fundamentals and Applications, Eds. Eslamian, S., CRC Press, Boca Raton, Florida, 346-377.

[23] Abuharara, A., 2017, Using isotopes to understand the origin of water and the effect of reinjection in the Los Azufers geothermal field in Mexico, Thesis, Department of Earth and Environmental Sciences, 
University of Waterloo, Canada.

[24] Sundhoro, H., Nasution, A., and Simanjuntak, J., 2000, Sembalun Bumbung geothermal area, Lombok Island, West Nusa Tenggara, Indonesia: An integrated exploration, Proceedings World Geothermal Congress, Kyushu-Tohoko, Japan, 28 May-10 June, 2000, 1785-1790.

[25] Cruz, V., Vargas, V., Matsuda, K., and Soeda, Y., 2013, Geochemical characterization of the Calacoa geothermal zone, Procedia Earth Planet. Sci., 7, 859862.

[26] Delmelle, P., Bernard, A., Kusakabe, M., Fischer, T.P., and Takano, B, 2000, Geochemistry of the magmatichydrothermal system of Kawah Ijen volcano, East Java, Indonesia, J. Volcanol. Geotherm. Res., 97 (1-4), 31-53.

[27] Torbehbar, A.K., and Sattari, S.M., 2015, Geochemistry and isotope study of discharged geothermal fluids, NW Sabalan geothermal field, NW Iran, Proceeding World Geothermal Congress 2015, Melbourne, Australia, 19-25 April 2015, 1-9.

[28] Besser, H., Mokadem, N., Redhaounia, B., Hadji, R., Hamad, A., and Hamed, Y., 2018, Groundwater mixing and geochemical assessment of low-enthalpy resources in the geothermal field of southwestern Tunisia, EMJE, 3 (16), 1-15.

[29] Óskarsson, F., and Ármannsson, H., 2015, Geochemical methods in geothermal surface exploration, Short Course $X$ on Exploration and Development of Geothermal Resources, UNU-GTP, GDC and KenGen, Lake Bogoria and Lake Naivasha, Kenya, 9 November-1 December, 2015.

[30] Wentao, B., and Bo, L., 2017, Hydrochemical and geochemical characteristics of geothermal water in Gedong area of Guizhou Province, J. Environ. Anal. Toxicol., 7, 488.

[31] Wishart, D.N., 2013, Geothermometry and shallow circulation of a low enthalpy system: The bath geothermal reservoir, Jamaica, Proceeding ThirtyEighth Workshop on Geothermal Reservoir Engineering, Stanford University, California, 11-13 February, 2013.

[32] Giggenbach, W.F., 1992, The composition of gases in geothermal and volcanic systems as a function of tectonic setting, Proc. Int. Symp. Water-Rock Interact., 873-878.

[33] Tian, J., and Pang, Z., 2017, Geochemical characteristics of gases from typical hightemperature geothermal systems in China, Procedia Earth Planet. Sci., 17, 500-503.

[34] Haklidir, M., and Haklidir, F.S.T., 2010, Hydrogen production from geothermal sources in Turkey, Proceedings World Congress 2010, Bali, Indonesia, 25-29 April 2010.

[35] Masoumi, R., Calagari, A.A., Siahcheshm, K., and Porkhial, S., 2017, Evaluation of hydrogeochemical and isotopic properties of the geothermal waters in the east of Mount Sabalan, NW Iran, Turk. J. Earth Sci., 26, 441-453.

[36] Strelbitskaya, S., 2005, Interpretation of chemical composition of geothermal fluid from the geothermal field of Baransky volcano, Iturup Island, Russia, United Nations University, UNU Geothermal Training Programme, Orkustofnun, Grensásvegur 9, IS-108 Reykjavík, Iceland.

[37] Wang, X., Wang, G.L., Gan, H.N., Liu, Z., and Nan, D.W., 2018, Hydrochemical characteristics and evolution of geothermal fluids in the Chabu hightemperature geothermal system, southern Tibet, Geofluid, 2018, 8532840.

[38] Kemboi, E., 2015, Evaluation of groundwater hydrogeochemical characteristics and mixing behaviour in Olkaria geothermal systems, Naivasha Kenya, Proceedings World Geothermal Congress 2015, Melbourne, Australia, 19-25 April 2015. 